\title{
DIVISAS O EMPRESAS HISTÓRICAS DE DAMAS. ALGUNOS TESTIMONIOS (SIGLOS XV Y XVI)
}

\author{
HISTORIC DEVICES OF LADIES. SOME TESTIMONIES \\ (15TH AND 16TH CENTURIES)
}

Sagrario López Poza, Nieves Pena Sueiro

Universidade da Coruña

ABSTRACT - Devices, badges or imprese, modalities of emblematics, were used by women between the 14th and 17th centuries, although less frequently than by men. This study analyses a little more than two dozen historical devices of ladies of the XVth and XVIth centuries from the perspective of emblematic genre theory. It deals with various aspects such as the structure, the personal involvement of the owners in the design of their devices, the purpose and manners of displaying wit employed in their composition, etc., and concludes that there are no noticeable differences between women's devices and the masculine ones, except that the imprese of ladies crafted for special occasions (to display in the course of celebrations -invenciones-) did not contain messages of praise to males nor amorous laments, which would have been interpreted as somewhat vulgar and in bad taste, according to the mentality of the time, while gentlemen produced a large number of amorous devices.

KEYWORDS: Emblem Studies; Devices; Badges; imprese; Women; Fifteenth Century; Sixteenth Century; Visual Culture; Middle Ages; Renaissance.

RESUMEN • Las divisas o empresas, modalidades de la Emblemática, fueron usadas por mujeres entre los siglos XIV y XVII, si bien con menos frecuencia que por los hombres. Este trabajo analiza poco más de dos docenas de divisas históricas de damas de los siglos XV y XVI bajo la perspectiva de la teoría del género emblemático. Se atiende a diversos aspectos como la estructura, la implicación personal de las propietarias en el diseño de sus empresas, la finalidad y procedimientos de agudeza empleados en su composición, etc., y se concluye que no se advierten diferencias notables entre las empresas femeninas y las masculinas, salvo en que las divisas ocasionales de las damas (para ostentar en festejos -invenciones-) no contenían mensajes de elogio a varones ni lamentos amorosos, lo cual hubiera sido visto, según la mentalidad de la época, como liviano y de mal gusto, mientras que los caballeros produjeron una gran cantidad de divisas amorosas.

PALABRAS CLAVES: Emblemática; Divisas; Empresas; Mujeres; Siglo XV; Siglo XVI; Cultura visual; Edad Media; Renacimiento. 
Las divisas o empresas han sufrido durante mucho tiempo el olvido de la crítica; en parte, por la excesiva especialización académica que hasta hace poco dificultaba aplicar enfoques interdisciplinares necesarios para una comprensión cabal de productos como estos, híbridos de palabra e imagen, para los que se requería un buen conocimiento de la tradición clásica. ${ }^{1}$ Especialistas en Historia del Arte, en lenguas y literaturas modernas, en Filología clásica, en Historia fueron los que, esporádicamente, dedicaron algunos estudios parciales a esta modalidad genérica de la Emblemática. Solo recientemente se ha notado un interés más integrador del estudio de divisas o empresas, por ejemplo en la base de datos Devise. Emblématique et héraldique à la fin du Moyen Age, creada por Laurent Hablot, de la Universidad de Poitiers, ${ }^{2}$ o la del grupo SIELAE de la Universidade da Coruña (proyecto BIDISO 5): Symbola. Divisas o empresas históricas, activa desde 2017 y dirigida por Sagrario López Poza y Nieves Pena Sueiro (López Poza, 2017). ${ }^{3}$ Estos recursos ayudarán a emprender nuevos estudios sobre esta modalidad de la Emblemática.

Como bien sabemos, los géneros (unos literarios, otros de distinta naturaleza artística) primero surgen con la práctica, y con ella se va creando una preceptiva consuetudinaria, a veces no expresa por escrito; solo bastante tiempo después, en ocasiones cuando el uso comienza a declinar, aparece la reflexión teórica que intenta registrar de forma categórica los rasgos genéricos distintivos y sus modalidades.

Las divisas o empresas, ${ }^{4}$ cuyos orígenes suelen situarse a mediados del siglo XIV, solo generaron alguna reflexión escrita que llegaría a la imprenta dos siglos después, cuando Paolo Giovio (1483-1552) expuso un año antes de su muerte, en su Dialogo dell'imprese militari e amorose, cinco condiciones que consideraba precisas para que una empresa fuera correcta. ${ }^{5}$ En el diálogo con Lodovico Domenichi, indaga sobre la historia del género de las empresas y se ocupa de 102 usadas por los personajes eminentes del momento o algo anteriores (reyes, personas ilustres, capitanes, famosos condottieri, cardenales, mecenas y escritores). Emite juicios de valor sobre el acierto o calidad de cada pieza e indica los motes, los motivos figurados y el significado de cada empresa -algunas de las cuales había diseñado él-. Su diálogo se publicó póstumo, en 1555, y no tenía los grabados xilográficos con que más adelante se enriquecieron ediciones posteriores.

Se conocen más las normas de Giovio porque fueron expuestas de forma sistematizada y dentro de una especie de catálogo de empresas; sin embargo, también encontramos indicaciones sobre cómo componer motes y divisas, así como las claves para entenderlas, en obras españolas de contemporáneos de Giovio, como por ejemplo Gonzalo Fernández de Oviedo (1478-1557), que posiblemente conoció a Giovio en Italia. En su obra Libro de linajes

1. Este trabajo se ha realizado en el marco del proyecto Biblioteca Digital Siglo de Oro 5 (BIDISO 5), con referencia: FFI2015-65779-P, financiado por el Ministerio de Economía y Competitividad del Gobierno de España y el Fondo Europeo de Desarrollo Regional (FEDER), 1-01-2016 a 31-12-2019, y se integra en el Grupo de Investigación Hispania (G000208) de la Universidade da Coruña.

2. Devise. Emblématique et héraldique à la fin du Moyen Age, base de datos, dirigida por Laurent Hablot, Centre d’Etudes Supérieures de Civilisation Médiévale, Université de Poitiers, [en línea] <http://base-devise.edel.univpoitiers.fr /index.php>

3. Symbola: divisas o empresas históricas, base de datos de BIDISO (Biblioteca Digital Siglo de Oro), A Coruña (España), [en línea] <https://www.bidiso.es/Symbola/>

4. La denominación de divisa tiene que ver con la tradición francesa y quienes la siguen, mientras que empresa remite a la denominación italiana. En España se usaron ambos nombres; en francés, devise; en inglés, device; en italiano, impresa. Para aclaración etimológica, ver Rolet (2007).

5. Las condiciones eran: la justa proporción entre alma y cuerpo, mote y figura; evitar la oscuridad, que no tiene por qué traducirse en claridad extrema; la belleza de la imagen; la exclusión de la figura humana; el empleo del mote, necesariamente breve, en una lengua diferente de la del que compone la empresa. 
y armas, escrita entre 1517 y 1523, que es un armorial con información sobre más de ochocientos linajes de gran antigüedad, se recogen divisas familiares de muy difícil datación. Contiene ilustraciones de escudos, pero no de las divisas; solo se indican los motes. ${ }^{6}$ Otra obra suya es aún más importante para nosotros, las Batallas y quinquagenas, voluminoso tratado de genealogía que le ocupó más de veinte años (1535-1556) y que da cuenta de 443 divisas, con detalles de mucho interés para comprenderlas. ${ }^{7}$

Otros contemporáneos, como Jerónimo Jiménez de Urrea (1513-1573), militar y escritor español procedente del noble linaje aragonés de los Aranda, también expusieron cuestiones de interés sobre la composición de las divisas, si bien no de forma sistemática como Giovio. En su Diálogo de la verdadera honra militar (1566), nos informa de que antiguamente las divisas las llevaban los caballeros al cuello, como los collares de las órdenes, y en las fiestas, en el pecho o la manga, y detalla la importancia que los colores tienen en las divisas, cuya interpretación difiere de los códigos de los escudos de armas.

La publicación del diálogo de Giovio y del Ragionamento de Domenichi ${ }^{8}$ suscitó profusas controversias acerca de la consideración del género de la divisa o empresa, su definición y naturaleza (si puede considerarse una metáfora -como la calificaría más tarde Emanuele Tesauro- o si se puede anexionar al campo de la Retórica, la Poética, la Lógica o la agudeza). Las discusiones se expresan sobre todo en Italia, en la segunda mitad del siglo XVI, en las obras de Girolamo Ruscelli, Luca Contile, Scipione Bargagli, Giulio Cesare Capaccio y Torquato Tasso, y podemos considerar que culminan con el monumental tratado de agudeza de Emanuele Tesauro Il Cannocchiale Aristotelico, publicado en Turín, en 1654, en que dedica un análisis exhaustivo a la especulación teórica sobre el género. En España, Juan de Horozco dedicó el primer libro de sus Emblemas morales (1589) a exponer sus consideraciones teóricas sobre las diversas modalidades emblemáticas. En Francia, los primeros planteamientos teóricos se perciben en los prólogos de los imitadores tempranos de Andrea Alciato (Graham, 2017), animados por el extraordinario éxito de su Emblematum liber (1531) y ya en el siglo XVII, con Henri Estienne y en los detallados tratados del jesuita Claude François Ménestrier, quien en 1686, en su Discours ou il est traité de la nature des devises, ${ }^{9}$ después de puntualizar que lleva 30 años creando divisas (la mayor parte para eventos festivos de la corte francesa), critica los excesos de las normas que se han ido acumulando sobre el género por parte de los teóricos. Él se atreve a realizar una clasificación de divisas en lo que denomina especies.

Consideramos una divisa o empresa a una representación simbólica compuesta de una imagen (con frecuencia de un animal, una planta o un objeto) a la que los que escribían sobre el género en el siglo XVI llamaban cuerpo, acompañada de una o varias palabras, a menudo en latín (mote o lema), mediante la cual la persona propietaria pretende transmitir la esencia (por eso también lo denominaban alma) ${ }^{10}$ de un ideal de vida, una intención elevada

6. Inédita en su totalidad, la obra se conserva en el Ms. 9-247 de la Biblioteca de la Real Academia de la Historia (Madrid).

7. En la actualidad existen dos ediciones de la obra, si bien ninguna está completa (los 4 vol. de la edición de Pérez de Tudela -1983-2002- y la de Avalle Arce -1989-). De los nueve manuscritos, sólo dos Ms. 9/5387 de la Real Academia de la Historia y Ms. 359 de la Biblioteca de la Universidad de Salamanca son autógrafos, en tanto que los otros siete son copias.

8. La primera edición del Diálogo de las empresas... de Giovio se publicó en 1555 en Roma, por Antonio Barré. En 1556 hubo dos ediciones: Venecia, a cargo de Ruscelli, por G. Ziletti (Ragionamento di monsignor Paolo Giovio sopra i motti e disegni d'arme e d'amore che communemente chiamano imprese) y otra por G. Giolito de' Ferrari, acompañada de un Ragionamento de Lodovico Domenichi. La obra sufrió refundiciones, censuras e interpolaciones de los editores, sobre todo de Ruscelli, que incluyó añadidos suyos.

9. Incluido en su obra La science et l'art des devises (1686), con paginación independiente.

10. No había consenso, sin embargo, entre los preceptistas. Ruscelli en un principio asumía, con Giovio, que el

IMAGO, NÚM. 10, 2018, 75-97 
(empresas heroicas) o una manifestación sobre la persona amada (empresas amorosas). ${ }^{11}$ Aunque se enviaban otro tipo de mensajes (religiosos, jocosos, etc.) no eran tan frecuentes como los heroicos o amorosos. Cuando la divisa se exponía en un acontecimiento efímero (fiesta, justa, torneo, etc.) solía ser denominada invención.

Así podemos ver la divisa de Margarita de Navarra (1492-1549), ${ }^{12}$ que ostenta como cuerpo unas flores de caléndula (el nombre de la flor varía según el idioma de los textos: franceses, fleur de soucy, y en otros italianos, calta fiore, y algunos en inglés sunflower; en cualquier caso, flores doradas como el sol), con el mote: "Non inferiora secutus», (en otras versiones "Non inferiora sequor») para transmitir que siendo esta flor afín al sol por la similitud de sus rayos con sus hojas y porque se vira hacia donde el astro se mueve, el corazón de Margarita es devoto de Dios, hacia quien dirige todos sus pensamientos, voluntad y afectos, contemplando las cosas altas, celestiales y espirituales sin aceptar destinos menores como se traduciría el mote. Se establece así una metáfora que identifica a Dios con el sol y a Margarita como la flor que le sigue. El mote procede de La Eneida, VI, 170. Claude Paradin recogió esta divisa de Margarita, tanto en la edición de 1551 como la de 1557 de Devises herö̈ques, y otros emblematistas también se hicieron eco de ella, como Giovanni Ferro, en su Teatro d'imprese, de 1623 [fig. 1].

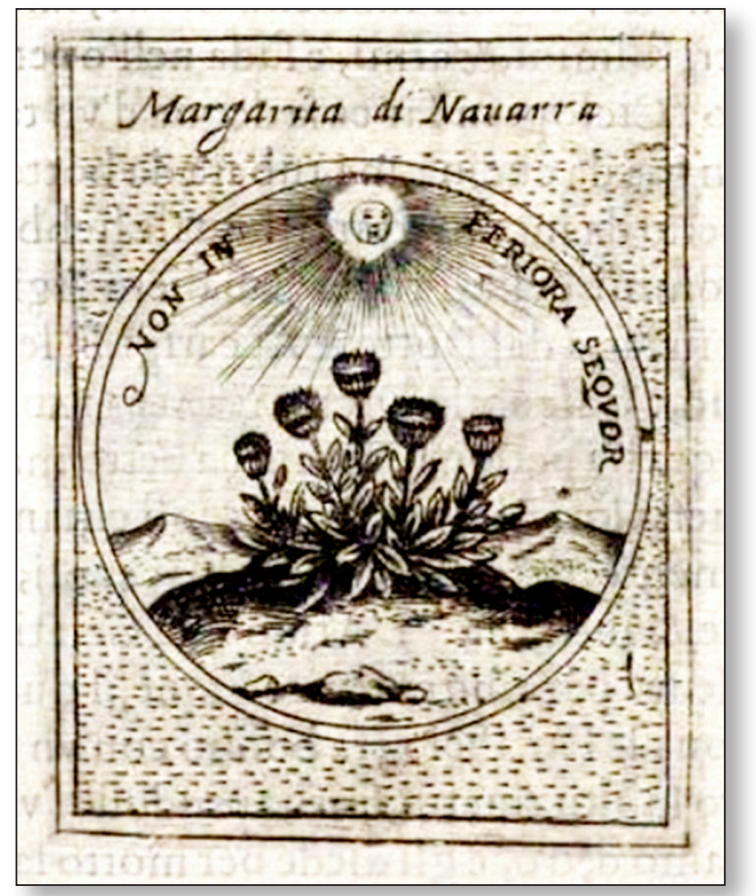

Fig.1. Divisa de Margarita de Navarra. Giovanni Ferro, Teatro d'imprese, Venetia, 1623. II: 152

\footnotetext{
alma radicaba en el mote, pero al publicar sus Imprese illustri en 1566, comentando que hay empresas con mote y otras sin él, considera que el alma radica en la intención de la empresa, su significado (Ruscelli 1566: A2r).

11. La praxis muestra que, además de estos dos tipos de mensajes, que son los más abundantes, en ocasiones se expresaban otros religiosos e incluso jocosos.

12. Margarita de Angulema, llamada también Margarita de Francia o Margarita de Orleans, noble francesa, princesa de la primera rama de Orleans de la dinastía de los capetos, duquesa consorte de Alençon (1509-1525), reina consorte de Navarra (1527-1549) por su matrimonio con Enrique II, escritora y humanista.
} 
Esta estructura ideal no siempre se dio en la práctica, sobre todo en los primeros tiempos, en que a menudo se emplearon divisas que solo fueron un mote, o divisas que a menudo solo se representaban con una imagen.

A pesar de la profusión de opiniones y análisis sobre el género de las empresas o divisas, solo recientemente se han comenzado a estudiar como un sistema de comunicación en que todos sus elementos han de considerarse: un emisor (el propietario) que emite un mensaje (por lo general una suma de palabra e imagen) mediante códigos simbólicos-asociados a los motivos figurados- que supone que conocen los sujetos receptores. El mensaje se transmite por una variedad de canales: pintado, bordado, tallado en piedra, en madera, en piezas de orfebrería, en grabados, etc. El contexto o situación (especialmente en la modalidad de las invenciones) coadyuvaría a una cabal comprensión del mensaje, difícil de descifrar pasados los siglos si no se conserva una aclaración coetánea de su significado.

\section{LAS DIVISAS O EMPRESAS Y LAS MUJERES}

Las divisas o empresas, ligadas con frecuencia a la cultura caballeresca, fueron usadas, principalmente, por varones. Como en otros muchos ámbitos de la vida social de la época que nos ocupa, disponemos de menos información sobre el uso que pudieron hacer las mujeres de este género, si bien sabemos que lo emplearon. Sin duda, algunas circunstancias tuvieron que influir en que el empleo de este sistema de comunicación lo usaran de manera más restringida las mujeres que los hombres. Los caballeros que participaban en torneos, justas y otros festejos de semejante naturaleza en las cortes, se veían obligados a ostentar una divisa (generalmente adornando las cimeras, bordadas en las gualdrapas de los caballos, etc.) que mostrara que poseían no solo destreza para el uso de las armas, sino talento e ingenio para componer una pieza de esta naturaleza, ya fuera para mostrar (como diría Ménestrier) los «sentiments héroïques» o para dejar en buen lugar a su dama ante la corte, manifestando elogios de su virtud, quejas de amor, etc. Algunas composiciones de estas usadas de forma ocasional requerían, además de una simple imagen y la palabra, de elementos parateatrales de su puesta en escena que justifican que las llamaran «invenciones».

Un testimonio del siglo XVI, anterior a 1544, puede inducirnos a pensar que en los festejos de que hablamos, no estaría bien visto que las damas ostentaran empresas. Nos referimos a Francisco de Monzón, en cuya obra manuscrita inédita Libro Primero del Espejo de la Princesa Christiana, ${ }^{13}$ y dedicada a doña Catalina, esposa de João III, rey de Portugal, para la educación de la infanta doña María, expresa claramente su rechazo a que las damas ostenten empresas:

debria la virtuosa prinçesa christiana de hazer otra: que vedase a las mugeres nobles y virtuosas que no truxesen empresas, porque es una señal de auer vendido y dado su castidad a aquel hombre cuya es y por cuyo amor la traen

Y un poco más adelante, tras recomendar que no se acepten justas ni torneos en honor de las damas honestas:

13. Se conserva en Lisboa, en el Arquivo Nacional da Torre do Tombo, Ms. 616. El manuscrito fue editado en 1997 por José Manuel Marques da Silva como "dissertação de Mestrado em História da Cultura Portuguesa" en la Universidad de Oporto, pero no se ha publicado. 


\begin{abstract}
las virtuosas mugeres zelosas de su fama y virtud, deben de huir de no dar consentimiento en que publiquen sus vanos deseos los que dizen que la aman con estos juegos y asomadas publicas, porque es de necesidad que si se sabe que por su voluntad se hicieron, que peligre su fama y corra risco (sic) su castidad y por quitar toda sospecha y occassion de perderla deben de ser tan virtuosas que no den consentimiento a que se hagan estas fiestas pregoneras de su infamia y tan prudentes que si supieren que algunos, a titulo de sus servidores las ordenan que no las vean ni oyan, porque con esto dan a entender que si el devaneo de los que las aman se las hizo ordenar que no fue por su voluntad pues que huyen de verlas y oirlas. ${ }^{14}$
\end{abstract}

Parece entender por empresas no tanto a divisas como las que nos ocupan como a un regalo realizado por el caballero que las pretende, o tal vez a ostentar los colores de la casa o blasón del caballero.

Pero otro tipo de divisas, las que tenían una vida más duradera y firme, llegaban a ser como tarjetas de presentación personal, una representación de los propietarios (ya fueran hombres o mujeres), que a diferencia del blasón (heredado de la familia) permitía mostrar particularidades de carácter, aspiraciones y anhelos, inclinaciones y afanes de la persona (lo que solían denominarse empresas heroicas en tratados posteriores) así como alusiones agudas o guiños a un público entendido en torno a acontecimientos conocidos sobre los que el propietario o propietaria desea transmitir algún mensaje. Estos tipos de divisas o empresas fueron las que sabemos que emplearon reinas, damas de la alta nobleza y otras mujeres ilustres.

Giovio menciona las empresas de algunas damas (principalmente porque él tuvo que ver con el diseño total o parcial) sin comentar nada que pueda hacer suponer que esas empresas habían de diferenciarse de las de varones. ${ }^{15}$ Son las empresas de Victoria Colona, marquesa de Pescara; María de Aragón, marquesa del Vasto; Leonor de Toledo, duquesa de Florencia y varias empresas de Isabella d'Este, marquesa de Mantua. Analizaremos unas cuantas divisas o empresas de damas que podemos considerar representativas del género, centrándonos en algunos de los aspectos característicos y determinativos de esta modalidad emblemática.

\title{
ATENDIENDO A LA ESTRUCTURA DE LAS DIVISAS O EMPRESAS
}

Si nos atenemos a la estructura de las divisas, observamos varias categorías: las que presentan los dos elementos generalmente considerados por los teóricos como constitutivos del todo (cuerpo y alma -imagen y palabra- mote y pictura), o las que carecen de una de esas partes. El padre Ménestrier (1686) explica que las divisas que solo consistían en el mote "furent tellement en usage le siecle passé pour tous les sçavants" (p. 18) es decir, que, por alguna razón, los humanistas distinguidos emplearon durante el siglo XVI divisas carentes de pictura. No queda claro si era considerado de buen gusto utilizar simplemente un mote, o bien se prescindía de la imagen por este tipo de usuarios al no tener que ostentar las divisas en juegos propios de caballeros.

La mayoría de las divisas que hemos analizado pertenecientes a mujeres se considerarían completas, pero entre las trece que hemos encontrado que utilizó Isabella d’Este (1474-

14. Francisco de Monzón, Libro primero del espejo de la princesa christiana, ms. s.XVI, fol. 231b-233a .

15. Todas las citas textuales que hagamos de Giovio se toman de la traducción al español de Alonso de Ulloa: Dialogo de las empresas militares y amorosas, Lyon, Guillielmo Rovillé, 1561. Sin embargo, las ilustraciones proceden de la edición de Lyon, Rovillé, 1574 debido a que ocupan menos espacio, ya que los grabados no llevan cartelas. 
1539), marquesa de Mantua, hallamos varias en que se dan todas las variantes: unas son «completas», pero otras solo constan de pictura o solo representan un mote, un anagrama o una cifra.

Giovio califica en su Dialogo a la que entonces era viuda del marqués de Mantua Francesco II Gonzaga, como señora «magnífica y generosa», y añade que «siendo combatida por la fortuna, tuvo ocasión de traer algunas», lo cual nos revela que las empresas se empleaban (y desde luego así lo hacía Isabella d'Este) como un sistema de comunicación para entendidos, ligado a acontecimientos vitales. Giovio menciona la anécdota que motivó una de las empresas de la marquesa, que se queja de la actitud de su hijo Federico, que había heredado el marquesado en 1519. Según Bregoli-Russo (1990: 172), el acontecimiento al que se alude debió de suceder entre 1522 y 1527 . Federico, enamorado de Isabella Boschetto, desdeñaba el consejo de su madre, que le instaba a una alianza conyugal con los Paleologhi de Monferrato (cosa que finalmente hizo, pero más tarde, en 1531). Durante el tiempo de su pasión, la madre de Federico fue quedando desamparada, permaneciendo solo como fieles suyos un par de caballeros, mientras que la amante de su hijo se lucía por la ciudad con un cortejo. Para mostrar su indignación, Isabella hizo pintar «en su palacio suburbano llamado Porto, y en el palacio viejo, una hermosa empresa a este propósito» [fig. 2] que fue:

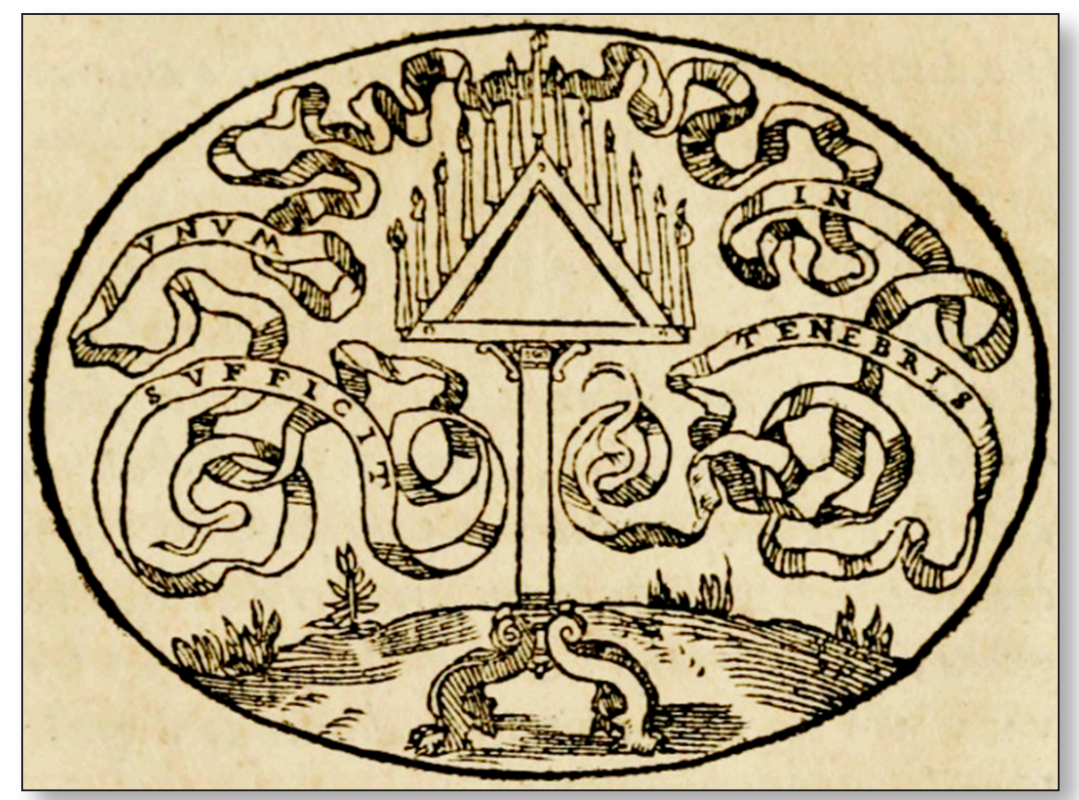

Fig. 2. Empresa de Isabella d'Este. Paolo Giovio, Dialogo dell'imprese militare et amorose, Lyon, 1574. 139.

un candelero hecho en triángulo, que en la Semana Sancta se acostumbra poner en las iglesias en el sacro Oficio de las Tinieblas, sobre el cual encendidas quince candelas, misteriosamente las apagan los sacerdotes una a una hasta que dejan encima una sola encendida, para dar a entender que la lumbre de la fe no puede perecer del todo ${ }^{16}$

16. Giovio, Dialogo de las empresas... p. 128-129

IMAGO, NÚM. 10, 2018, 75-97 
Esta empresa, como otras de Isabella, no llevaba mote, y Giovio le añade uno: «Sufficit unum in tenebris" (una sola basta entre tinieblas), con que aleja lo enigmático de la versión sin mote, y deja patente su elogio por la marquesa. ${ }^{17}$ Otras empresas de Isabella d'Este carentes de mote y que menciona Giovio son:

un manojo de pólizas blancas que se sacaban de un vaso de las suertes, queriendo decir que había tentado muchos remedios y todos le habían salido en blanco como suerte; pero, al cabo, salió vencedora de sus émulos, tornando a su primer grandeza [fig. 3]. ${ }^{18}$

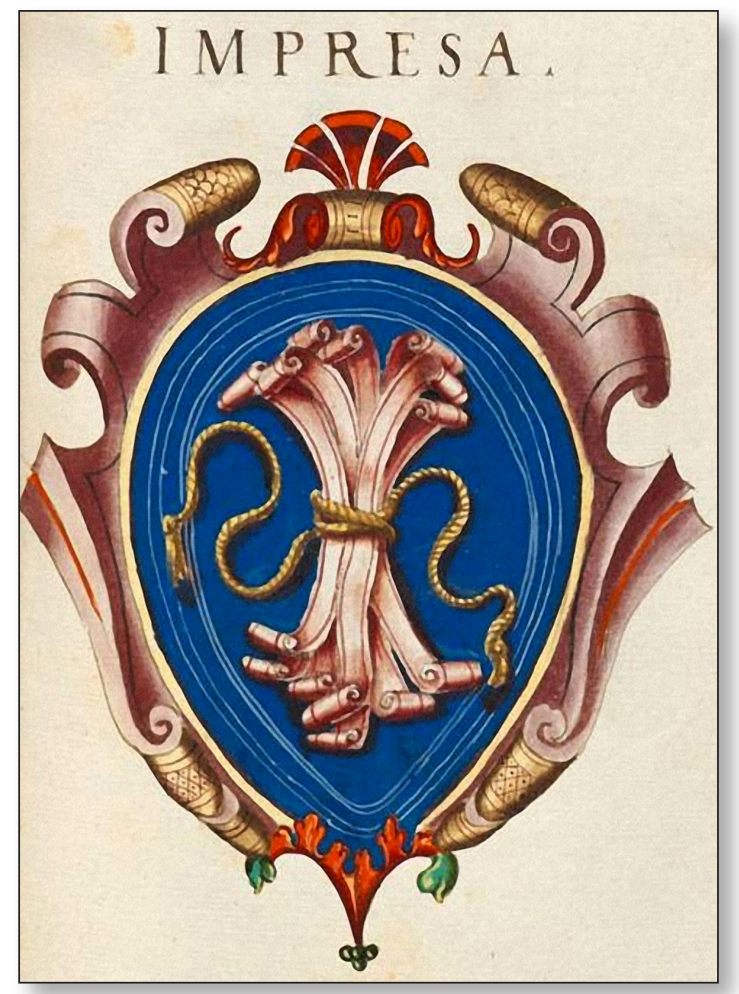

Fig. 3. Empresa de Isabella d'Este. Insignia... IX. BSB Cod. icon. 274

Muy famosa fue, entre las empresas de Isabella d'Este -aunque Giovio no la mencione- una sin mote, conocida como «impresa delle pause» (es decir, de las pausas o silencios musicales) y que, como otras, decora el Studiolo o Grotta de la marquesa en el palacio ducal de Mantua y aparece en exquisitas piezas de mayólica de los Este-Gonzaga diseñadas por Nicola da Urbino. ${ }^{19}$ La pictura muestra un pentagrama musical, que solo contiene signos de

17. Esta empresa se usó al menos desde 1512. Ver Giuseppe Gerola, 'Un'impresa ed un motto di casa Gonzaga', Rivista d'arte 12 (1930), 389-90.

18. Giovio, Dialogo de las empresas... p. 128-129.

19. Para más información, consultar en la base de datos Symbola, la ficha elaborada por López Poza, $2018<$ https:// www.bidiso.es/Symbola/divisa/153>. 
silencios [fig. 4]. Mario Equicola, que durante años fue tutor de Isabella y desde 1519 su secretario, al elogiar a la marquesa y su grotta, explica que esta empresa es un símbolo de la prudencia, de saber cuándo uno debe cantar (o hablar) y cuando permanecer silencioso:

recuerdo que el sabio Biante decía que a menudo lamentaba no haber permanecido en silencio. Esto lo ha significado la muy prudente Isabella d'Este, marquesa de Mantua, en una ingeniosa imagen con todos los restos de música práctica, que nos advierte a nosotros y a los que tengan voz viva diciéndoles «permanece silencioso en el momento oportuno». ${ }^{20}$

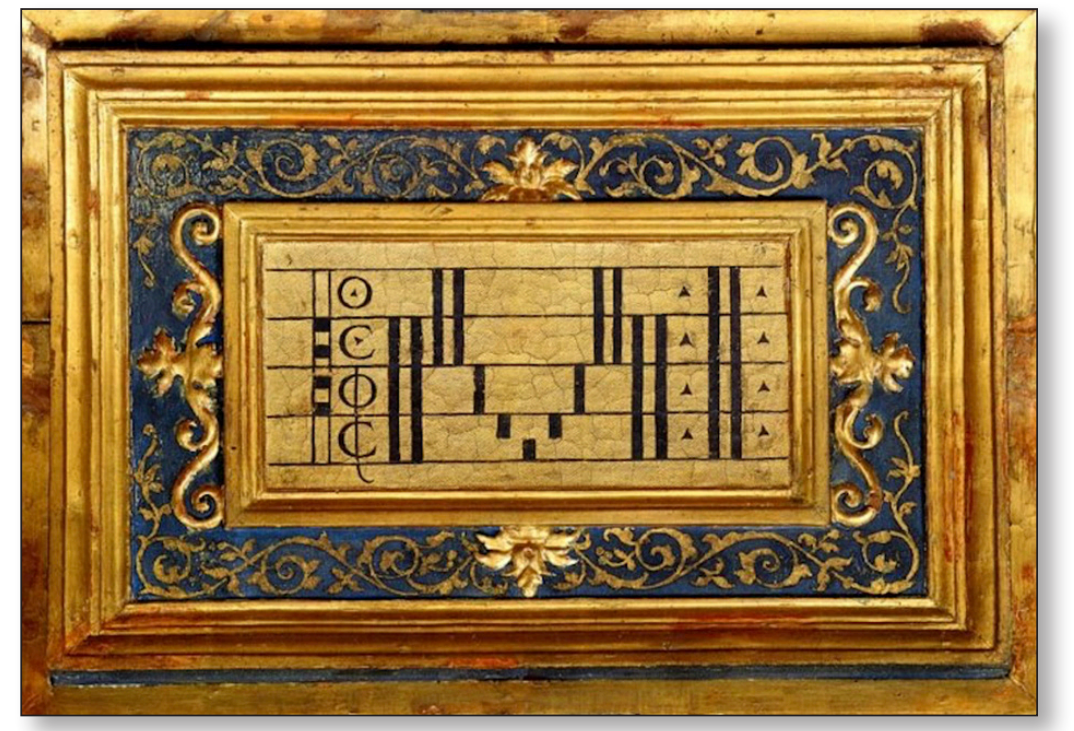

Fig. 4. Empresa «delle pause» de Isabella d'Este. Studiolo, Palacio Ducal. Mantua

Las escenas de las piezas de mayólica en las que también aparece esta empresa parecen confirmarlo, pues aluden a comportamientos prudentes e imprudentes, como la que representa la contienda musical de Apolo y Pan, con la imprudente intervención de Midas, por la que Apolo le castiga con unas orejas de burro, escena basada en las Metamorfosis de Ovidio 11.150-93 (ver Rasmussen, 1989: 110-112). Es interesante el hecho de que Isabella luciera esta empresa bordada en su vestido en 1502, en la boda de su hermano (Alfonso d'Este) con Lucrecia Borgia, rival de Isabella e hija natural de Rodrigo Borgia (el papa Alejandro VI), sobre la cual se difundieron muchos rumores criticando su amoralidad. Con su atuendo, Isabella estaría pregonando que se proponía ser prudente y no hablar sobre las muchas cosas que podría decir de su cuñada.

Algunas divisas no sabemos si no tuvieron mote o, sencillamente, no se ha conservado, pues los lugares donde nos quedan vestigios son esculturas o soportes no propicios para escribir. Es el caso de la divisa de Catalina de Lancaster, esposa de Enrique III de Castilla, que ya existía hacia 1404 y es «la primera divisa femenina regia documentada en la Castilla Trastámara» (Fernández de Córdoba, 2016). El motivo es una piña piñorea, que aparece en

20. Traducción nuestra, de Libro de natura de amore, manuscrito conservado en la Biblioteca Nazionale Universitaria de Turín. (Ver Shephard, 2011: 701).

IMAGO, NÚM. 10, 2018, 75-97 
diferentes lugares del monasterio de Santa María la Real de Nieva (Segovia), como señal del patronazgo de Catalina: en capiteles del claustro [fig. 5], en el dintel de la puerta que comunica la capilla mayor con la capilla lateral izquierda (en este caso, la piña es dorada), y en el llamado Mirador de la Reina «enmarcado por piñas que funcionan como presentación deíctica de la soberana facilitando la visualización del poder» (Fernández de Córdoba, 2016: 122). También hallamos su divisa en otros lugares beneficiados por la reina, como Mayorga, en cuya iglesia de Santa María de Arbás (Valladolid), se reproduce su divisa repetidamente en los yesos policromados mudéjares y en uno de los nervios del ábside.

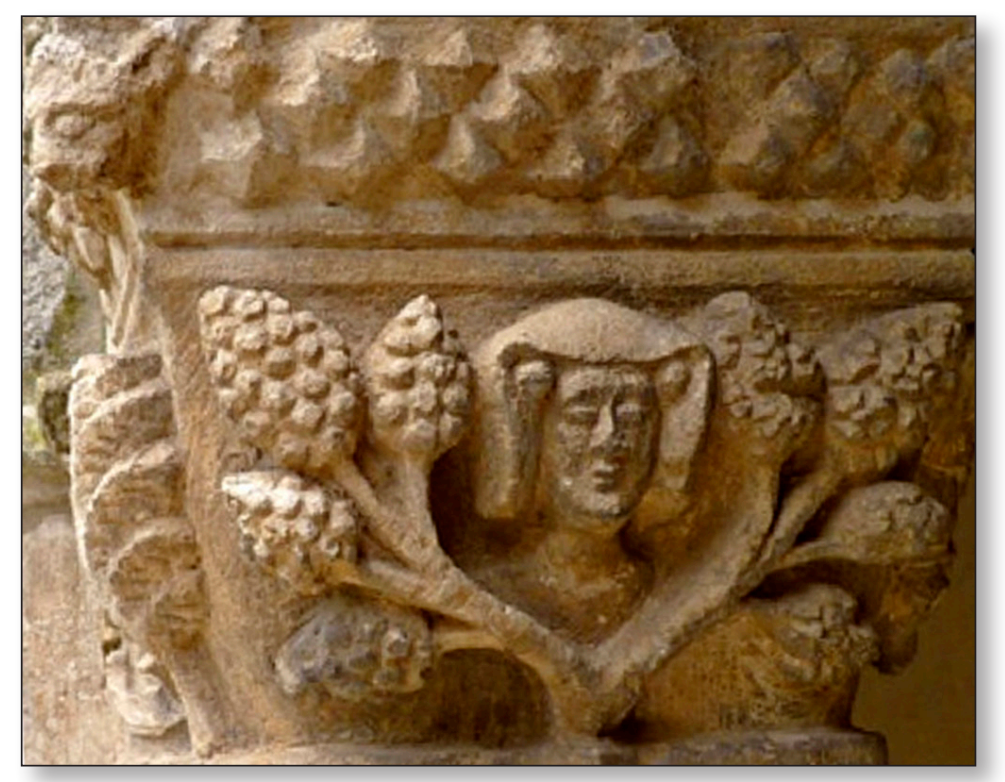

Fig. 5. Capitel del claustro de Santa María la Real de Nieva. Segovia

Los mensajes de las divisas que como esta carecen de mote resultan muy difíciles de interpretar. Se ha asociado la piña de la reina Catalina con la fertilidad, pero parece más plausible que el significado de su divisa sea algo más parecido a lo que más tarde expresó en su emblema 37 el médico y humanista holandés Adriano Junio (1511-1575), con una piña como motivo y el lema: «Virtus difficilis, sed fructuosa» (la virtud es difícil, pero rica en frutos). Junio declara que la piña piñonera es áspera por fuera, con prominencias o pequeños escalones de admirable dureza que encierran los dulces piñones, que harían recordar el trabajo arduo realizado, que nace de la virtud, conseguida con esfuerzo. ${ }^{21}$ Picinelli en su Mundus symbolicus (lib. IX, cap. 28) indica otros motes y significados asociados, que no podemos comentar aquí por falta de espacio.

Otra posibilidad, frecuente sobre todo en los primeros tiempos de uso de las divisas, era emplear un juego de palabras o charada que podía hacer coincidir en una lengua concreta el nombre del motivo representado con lo que se pretende transmitir como mote. En el siglo XV, la reina María de Castilla, reina de Aragón entre 1416 y 1458, ejerciendo como lugar-

21. Ver la traducción y notas de los emblemas de Junio de Beatriz Antón y Antonio Espigares (2013: 272-273). 
teniente por ausencia de su esposo, Alfonso V el Magnánimo, empleó al menos dos divisas (Narbona, 2014-2015), que ostentaban como cuerpo una olla ardiendo sobre la que se ven siete llamas, y una mata con tres flores de azafrán, además de otras que se habían convertido en divisas familiares del linaje Trastámara (las de las órdenes de la Jarra y el Grifo y la de la orden de la Banda castellana). No se han conservado motes de estas divisas, aunque pudieron tenerlos. Narbona apunta la posibilidad de que el mismo nombre de la planta del azafrán, en catalán medieval, ( «safrá» o "sefrá») evocaría el mensaje que la reina deseaba transmitir: su sufrimiento (tenía salud muy frágil, no podía tener hijos y vivió alejada de su esposo, que estaba en Italia), lo que, unido a los estigmas rojos de la planta, mostraría su caridad (Hablot, 2008). La otra divisa, de un crisol (crucibulum o cruceolum) mostraría la colaboración de la soberana, a través de sus tribulaciones, en la tarea de la Redención. Las siete llamas simbolizarían las siete palabras pronunciadas por la Virgen a los pies de la cruz. Narbona las ve como divisas parlantes, y mientras no hallemos (si es que lo hubo) un mote que las complete, no quedará satisfactoriamente aclarado el enigma de su significado pleno.

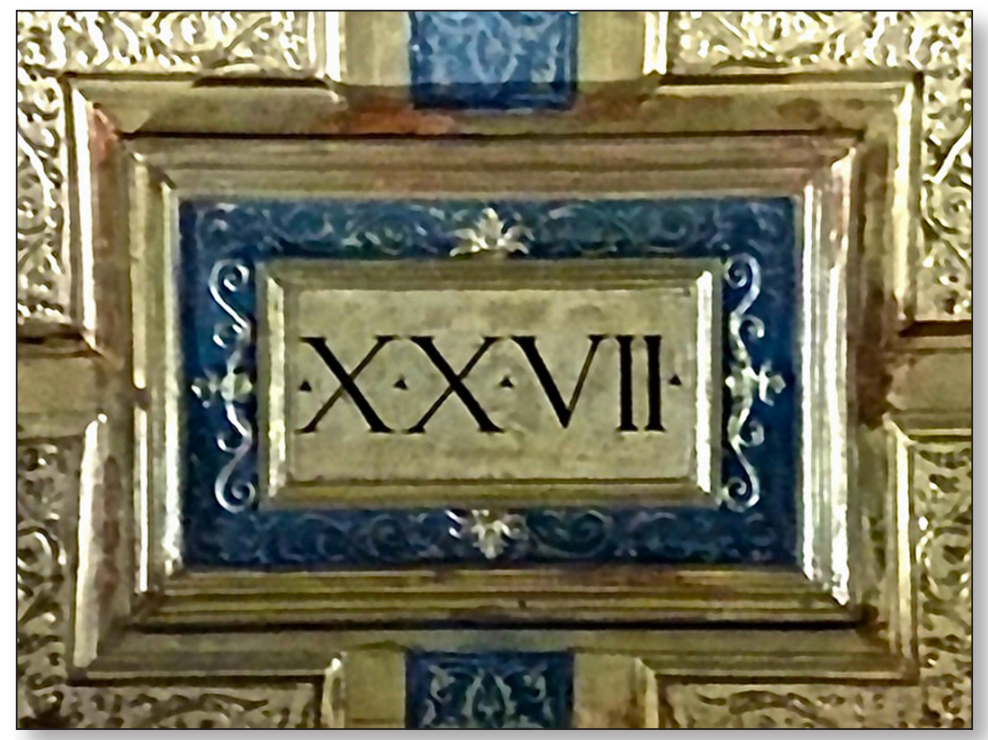

Fig. 6. Empresa de Isabella d'Este. Studiolo. Palacio Ducal. Mantua

Entre las empresas sin cuerpo (solo con mote, o monogramas, o cifras) empleadas por Isabella d'Este, fue muy famosa y enigmática (esta citada también por Giovio) que solo lleva representada una cifra en números romanos: XXVII [fig. 6], que se leería en italiano: «vintisette» o "vinti-i-sette» (literalmente, vencidos los siete). El mensaje se expresa como una charada, y por tanto es difícil para un receptor que no esté al tanto de la situación. Para Giovio (y más tarde el padre Ménestrier) era un mensaje a sus enemigos Vinti sete (habéis sido vencidos); sin embargo, algunos críticos posteriores (Bonoldi, 2015: 26-27) creen que ha de entenderse que ella había vencido los siete pecados capitales; es decir, que era una dama virtuosa.

Consciente de las ambigüedades a que llevaba este tipo de empresas, que empleaban la agudeza verbal más que la conceptual, Giovio critica como desacertado su uso, aunque se 
siente condescendiente con la marquesa a quien debe favores, y comenta (p. 130) «este mote, aunque participa del vicio arriba dicho, todavía se permite en una mujer y tan gran señora."

Otra de las más famosas (y la más personal) de las empresas de la marquesa de Mantua (no comentada por Giovio) también carece de cuerpo. Es solo una sentencia: «Nec spe nec metu» (Ni por el interés ni por el miedo) ${ }^{22}$ que aparece en varios lugares del palacio ducal de Mantua, y en especial en el techo de la grotta de Isabella. Tiene esta empresa de particular que fue ideada por la misma marquesa antes de 1504, según se desprende de una carta de esa fecha:

Nec spe nec metu che fu l'impresa d'Isabella d'Este Gonzaga, da lei stessa inventata prima del 1504 , che di tale anno è una lettera di lei a un ambasciatore Cesareo al quale fa dono di quella impresa, concedendogli di usarla, scriverla, portarla, etc. «in quel modo et forma che noi putemo et facemo che siamo state la inventrice, et habiamola facta nostra impresa peculiare». Mario Equicola aveva su di essa scritto un libro «de circa quarenta carte», libro che fu stampato ma che non è giunto sino a noi: e di cui argutamente la stessa Isabella scriveva alla Cantelma che quel motto "da noi cum tanti misterii non fu facto ci, quanti lui gli attribuisse». [Luzio y Renier, (1899) p. 50-51, en n.]

El antiguo tutor de Isabella, Mario Equicola, escribió en latín, como regalo de cumpleaños a la marquesa, un diálogo que llevaba por título: Nec spe nec metu, ${ }^{23}$ con intención de glosar el significado de la empresa, que sin embargo no entusiasmó a Isabella, por considerar la obrita erudita y filosófica en exceso, según deja trascender en una carta a Margherita Cantelmo (López Poza, 2011). El diálogo se estructura en 27 párrafos, lo cual parece haber sido hecho a propósito para coincidir con la misteriosa empresa del «XXVII» de Isabella.

\section{ATENDIENDO A LA IMPLICACIÓN PERSONAL EN EL DISEÑO DE LAS DIVISAS}

Hay diferencias entre empresas en cuyo diseño y proceso de la inventio su propietario estuvo implicado, aunque de la realización final se ocupara una persona cualificada en letras humanas, y aquellas en que el propietario fue pasivo, o incluso ajeno a la creación de su divisa. Hemos visto que Isabella d'Este fue muy activa en la realización de sus empresas, tanto por lo que expresan sobre ella misma (admiración por los estoicos) como por emplear las divisas para expresarse en acontecimientos de su vida personal, etc. La marquesa fue excepcional en ese sentido, pues la mayor parte de las divisas o empresas de mujeres fueron -como muchas de varones- elaboradas por humanistas a su servicio, que realizaban estas composiciones para personas ilustres -como hizo el mismo Giovio- bien como encargo o como agasajo voluntario.

22. Spes ha de entenderse como expectativa en lograr algo (no con el sentido de la virtud teologal esperanza). El concepto procede del estoicismo y está ligado a la impasibilidad deseable en el sabio, su constancia de ánimo. Séneca lo emplea en las cartas a Lucilio aunque no use la misma fórmula, sino "non spes, non timor». Está refiriéndose a la amistad auténtica, «que ni la esperanza, ni el miedo, ni la preocupación por el propio provecho son capaces de destruir, y, a su vez, es con la que mueren y por la que mueren los hombres» (...quam non spes, non timor, non utilitatis suae cura diuellit, illius cum qua homines moriuntur, pro qua moriuntur -epist.6.2-). Ver López Poza, 2011 para más detalles sobre esta empresa.

23. Marii Equicoli Oliuetani Nec spe nec metu. Dialogus ad Iulianum Medicem (Mantuae, per Francischum Braschum, 1513 die xxvii Nouembris) [36] c.; $4^{\circ}$. 
Veamos, como ejemplo, algunos casos de ilustres damas. De la emperatriz Isabel de Portugal (1503-1539), esposa del emperador Carlos I, conocemos dos divisas: una - "Aut Caesar aut nihil»- de la que no se conoce pictura, que parece deberse a elección personal de Isabel, y que expresa una sentencia atribuida por algunos a Julio César, usada como mote por Ladislao I d'Angiò-Durazzo, rey de Nápoles (1376-1414) y adoptada luego como divisa por César Borgia (1475-1507). Isabel la empleó cuando era infanta de Portugal y recibía presiones para matrimoniar. Con su divisa manifiesta su determinación a casarse con su primo, el rey Carlos I de España, emperador del Sacro Imperio Romano Germánico, o no casarse con nadie. ${ }^{24}$ La otra divisa [fig. 7], claramente fue realizada sin su participación, pues de lo contrario habría que tacharla de vanidosa, algo inverosímil. Fue su esposo quien la encargó, y es una divisa completa, cuya pictura representa «las tres Gracias» y su mote reza: "Has habet et superat" (las tiene y las supera) para poner de manifiesto que a Isabel la adornaban no solo las virtudes de las Tres Gracias (Aglae, Eufrosina y Talía según la mitología clásica), sino que superaba a estas. ${ }^{25}$

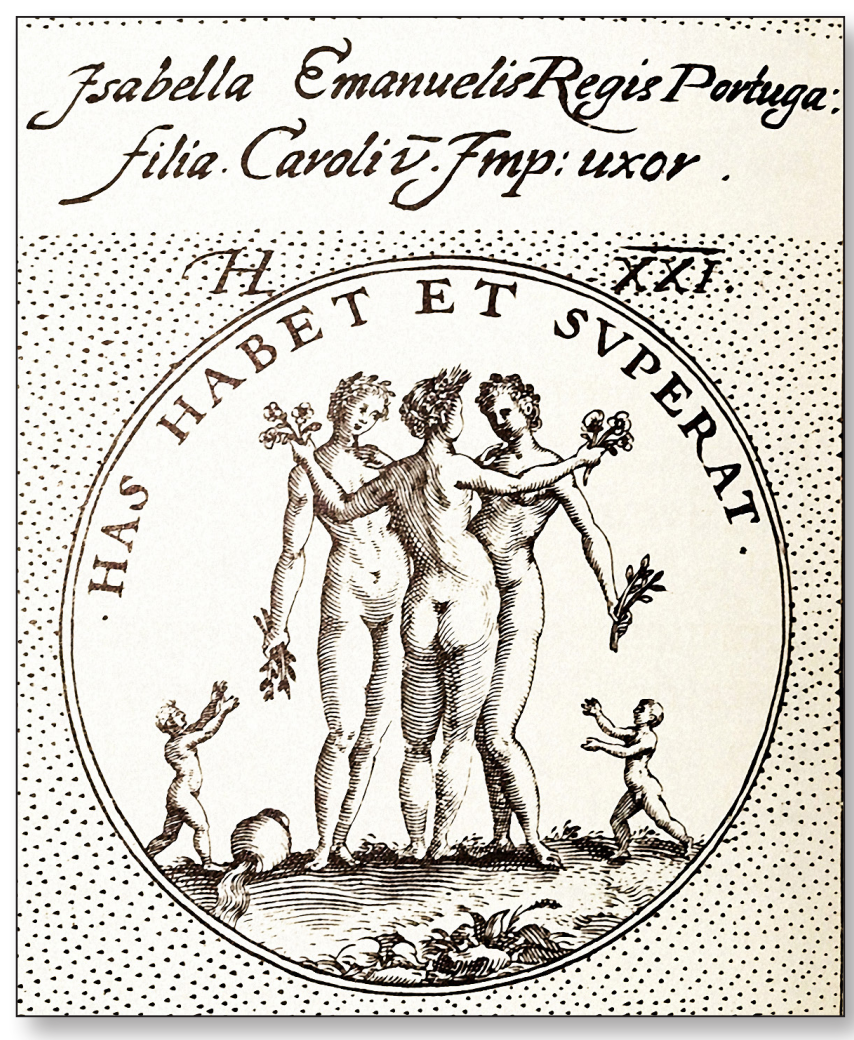

Fig. 7. Jacobus Typotius, Symbola Divina $\theta$ Humana, Praga, 1601. I, lám. 20, XXI

24. Para más detalle, véase la ficha en Symbola: <https://www.bidiso.es/Symbola/divisa/183> 25. Véase la ficha en Symbola: <https://www.bidiso.es/Symbola/divisa/184>

IMAGO, NÚM. 10, 2018, 75-97 
Catalina de Médici (1519-1589), reina de Francia, empleó varias divisas, alguna de las cuales parecen haber sido ideadas por expertos asesores, que con sutileza promueven el papel de Catalina en un reino extranjero. La empresa que presenta como pictura un arco iris sobre un mar agitado y un cielo encapotado, del que sale lluvia por la derecha, mientras que a la izquierda luce el sol [fig. 8], lleva un mote en lengua griega (moda seguida en Francia

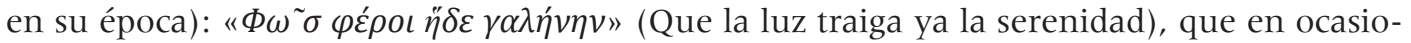

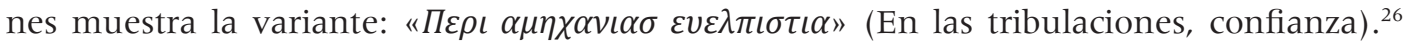
Catalina, incluso antes de ser reina, es hábilmente presentada como mediadora entre lo divino y lo humano, como portadora de sosiego. El arco iris anuncia la paz y la tranquilidad tras una tormenta, y expresa una actitud prudente: que, ante las aflicciones y pesadumbres, uno ha de mantenerse esperanzado. La corte comprendía un mensaje personal de la reina, que afrontó con serenidad durante los primeros diez años de su matrimonio su infertilidad (con riesgo de ser repudiada por su esposo, entregado a su influyente amante, Diana de Poitiers), hasta su inesperada fecundidad posterior (tuvo diez hijos con el rey, entre los que cinco llegaron a ser reyes o reinas).

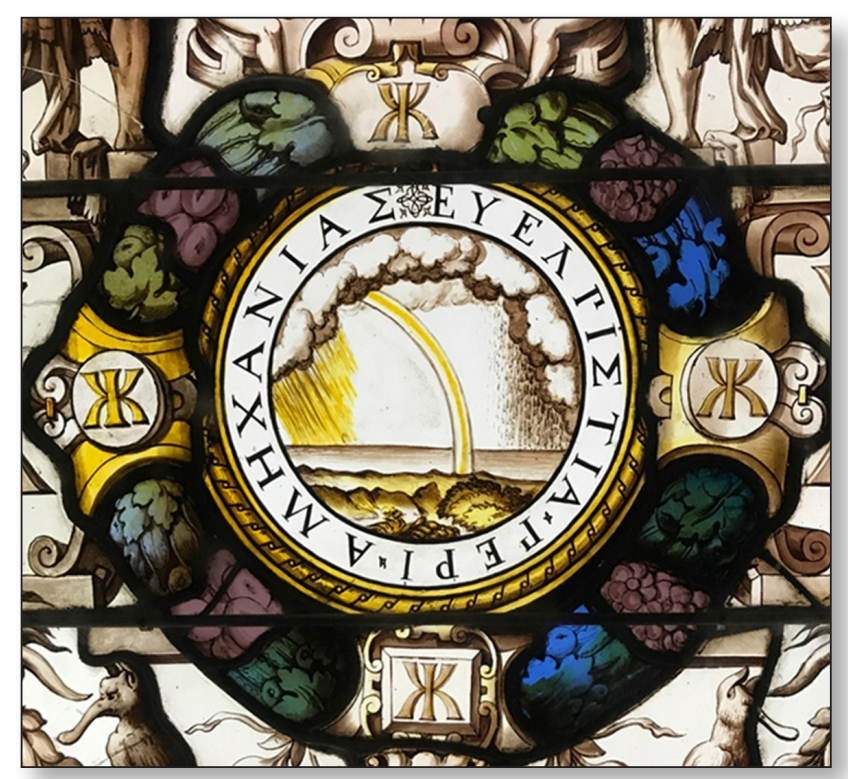

Fig. 8. Divisa de Catalina de Médici. Château d’ Écouen (Francia)

En otra divisa de Catalina [fig. 9)], se advierte más participación personal en la inventio. Nos referimos a la que muestra en la pictura una lanza de torneo rota en dos partes, con el mote: "Lacrime hinc, hinc dolor» (de aquí las lágrimas, de aquí el dolor), con que expresa su pesar como viuda por la muerte de su esposo, Enrique II de Francia, en un torneo, al clavársele una astilla de la lanza de su adversario en un ojo. ${ }^{27}$

26. Véanse las fichas de Symbola: <https://www.bidiso.es/Symbola/divisa/l86> y <https://www.bidiso.es/Symbola/divisa/192>

27. Para ampliar detalles, ver la ficha en Symbola: <https://www.bidiso.es/Symbola/divisa/193>. 


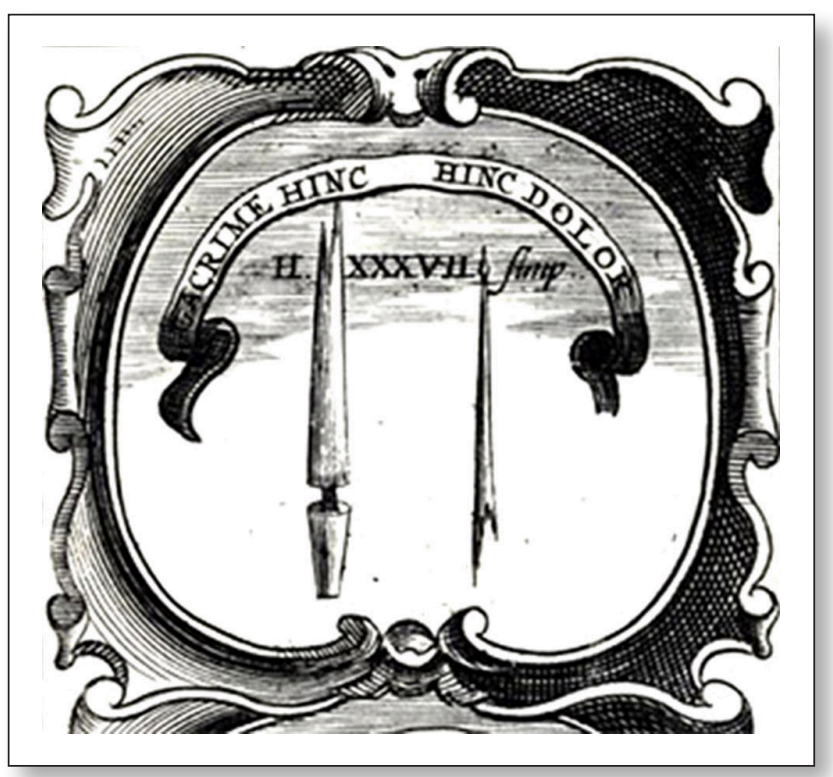

Fig. 9. Divisa de Catalina de Médici. Jacobus Typotius, Symbola Divina $\theta$ Humana, [s.n.], 1666. 256

Se conoce otra empresa de Catalina —aunque no sabemos si llegó a usarla- en cuyo proceso de la inventio no tuvo participación alguna. Lleva por mote: "Fato prudentia maior» (la prudencia supera al destino) y la pictura es una estrella de ocho puntas brillando en el interior del círculo que forma una serpiente uróboros coronada. ${ }^{28}$ Fue creada por Gabriele Simeoni para la reina -con mote de las Geórgicas de Virgilio, I, 415-416-, considerando que se ajustaba bien a su persona, porque a pesar de su buena y virtuosa estrella por ser descendiente de reyes, papas y nobles, decidió vivir con gran virtud, modestia y paciencia, destacando así entre las más dichosas y respetadas reinas de Francia. Es, pues, una creación panegírica, de elogio. Ménestrier alude a esta clase de divisas como atribuidas: «Devises attribuées, ou faites en forme d'êloge pour loüer quelqu'un». ${ }^{29}$

Entre todos estos casos de grados diversos de participación de la propietaria de la empresa, la reina María Tudor adoptó una divisa sin cuerpo en 1553, tal vez siguiendo una sentencia que formuló Tomás Moro en tiempos de suma amenaza: "Time always trieth out the Truth» (el tiempo siempre clarifica la verdad $)^{30}$ y que llegó a ser un mote familiar, pues Enrique VIII lo empleó y, después de María, su hermanastra Isabel I también lo usó, si bien con sentidos diferentes. El mote de María «Veritas Temporis Filia» presenta a la reina como portadora de la Verdad, largamente sometida desde que su padre, Enrique VIII, para poderse casar con Ana Bolena, repudió a su madre, Catalina de Aragón, para lo cual hubo de separarse de la Iglesia Católica romana y asumir él la cabeza de la Iglesia Anglicana de Inglaterra; un cataclismo para el reino. Otros, en cambio usaron el mote para significar que la Verdad Cristiana había de ser rescatada de la hipocresía católica de Roma.

28. Ver en Symbola la ficha: <https://www.bidiso.es/Symbola/divisa/187>

29. Discours ou il est traité de la nature des devises, p. 56. En la edición de La science et l'art des devises (1686).

30. Thomas More, The Supplycacyon of Soulys agaynst the Supplicacyon of beggars, Londres, William Rastell, 1529.

IMAGO, NÚM. 10, 2018, 75-97 
María empleó otras divisas, entre ellas una que partió del diseño de una medalla (pareja de otra de su esposo Felipe) realizada por Jacome Trezzo en 1555, con lema "Caecis visus timidis quies» -vista para el ciego, tranquilidad para el temeroso- [fig. 10]. María, representada como matrona coronada, portando una palma, un ramo de olivo y una antorcha con que prende despojos militares, se presenta como reina portadora de paz para los perseguidos católicos, y anuncia un nuevo gobierno estable y sin guerras de religión en Inglaterra (simbolizado por el templo de Jano, cerrado). ${ }^{31}$

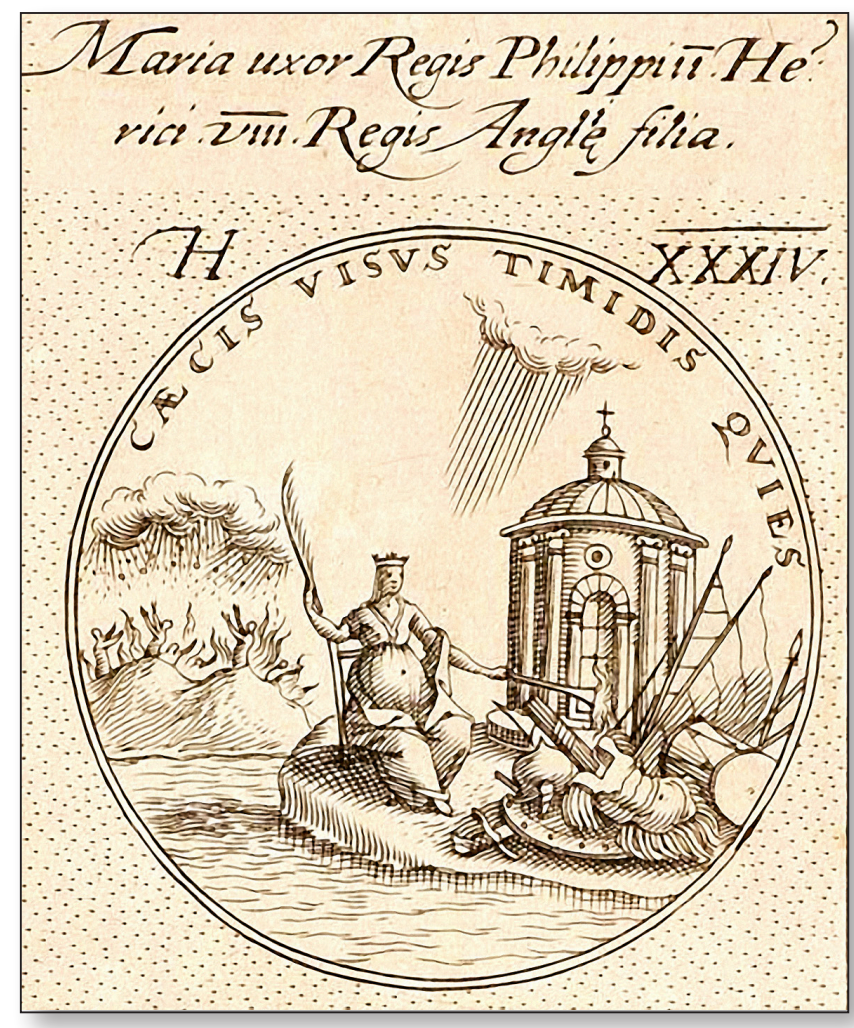

Fig. 10. Divisa de María Tudor. Jacobus Typotius, Symbola Divina e Humana, Praga, 1601. I, lám. 33, 73

\section{ATENDIENDO A LA FINALIDAD}

Gran parte de las divisas que hemos comentado tienen como propósito bien la manifestación de un rasgo de carácter personal considerado positivo por la comunidad, difundir las buenas cualidades o virtudes de una gran señora (en este caso divisas de elogio) o claramente la propaganda. Suelen ser divisas ideadas para durar; en muy contados casos son ocasionales, destinadas a aludir a un acontecimiento concreto (como la del candelabro de

31. Detalles amplios sobre las dos divisas que citamos de María Tudor pueden hallarse en la base de datos Symbola, buscando por el mote o por la propietaria (fichas 101 y 246). 
Isabella d'Este) y aun menos se encuentran las que eran tan frecuentemente usadas por los hombres: las ocasionales que a menudo reciben el nombre de invenciones, ligadas a la puesta en escena en torneos y justas (como la de Marina de Aragón que comentaremos más abajo).

Giovio cita varias que podemos encuadrar entre las primeras, como la empresa de la señora Victoria Colona, marquesa de Pescara. El propio Giovio le diseñó la empresa, que mostraba como cuerpo unos peñascos en medio del mar embravecido, con el mote: "Conantia frangere frangunt» [fig. 11], para indicar que su virtud, como los peñascos firmes, soportan las olas bravas, rompiéndolas y convirtiéndolas en espuma, en alusión a que esta señora «siendo pía y liberal para con todos, no dejó de tener envidiosos y malos que le daban enojo y estorbaban sus altos pensamientos, pero como sabia matrona consolábase con que los tales, pensando hacerle mal, se destruían ellos mesmos»(p. 103).

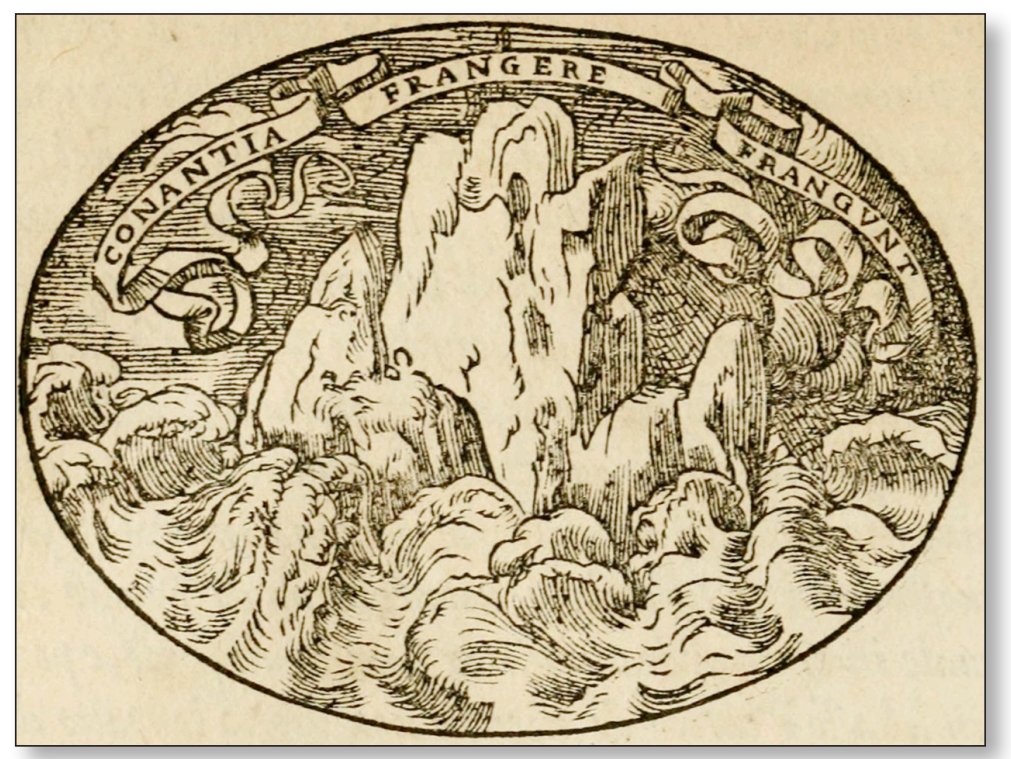

Fig. 11. Empresa de Victoria Colonna. Paolo Giovio, Dialogo dell'imprese militare et amorose, Lyon, 1574. 112

La empresa de doña María de Aragón, marquesa del Vasto [fig. 12], fue también diseñada por Giovio a petición de ella, que le comentó que tenía mucho cuidado con la honra y castidad no solo suya, sino de sus damas (doncellas o casadas). Giovio escogió como cuerpo dos manojos de mijo maduro, atados el uno al otro, con un mote que decía: «Servari et servare meum est» (es decir: «Mis propiedades son conservarme y conservar». Esa empresa la había colocado Giovio en el atrio de su museo en su villa a orillas del lago de Borgovico (Como, Italia), lamentablemente desaparecida hoy en día, seguramente junto al retrato de la marquesa. ${ }^{32}$

\footnotetext{
32. La villa de Giovio fue famosa por albergar gran cantidad de retratos de hombres famosos, en parte conservados hoy en la Pinacoteca Civica de Como. El proyecto de Giovio era realizar una galería de retratos de hombres ilustres para lo cual le enviaban un retrato que colocaba en su galería, y al lado ponía, si disponía de ella, la empresa del hombre o mujer ilustre y siempre un elogio (un epigrama, escrito por distintos autores) que sintetizaba la personalidad del retratado. Sobre el Museo de Giovio, ver Sonia Maffei, 1999, pp. 111-179.
}

IMAGO, NÚM. 10, 2018, 75-97 


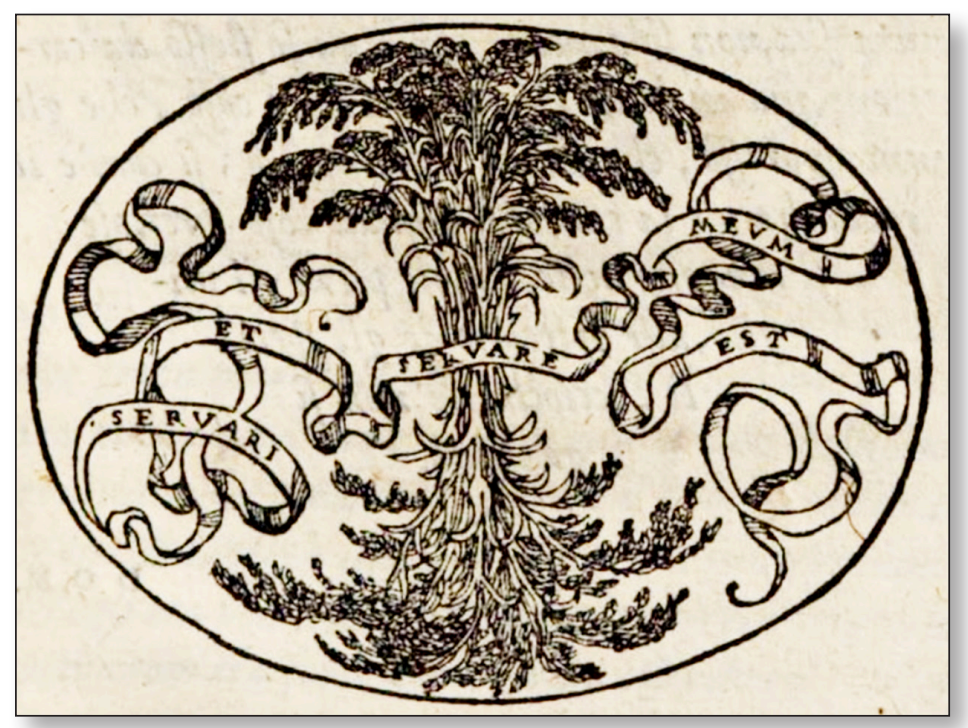

Fig. 12. Empresa de María de Aragón. Paolo Giovio, Dialogo dell'imprese militare et amorose, Lyon, 1574. 113

Para Leonor de Toledo, esposa de Cosme de Médici, duque de Florencia, confiesa Giovio haber diseñado una empresa para el envés de una medalla «que puede aprovechar para labores», cuya pictura era "una pava en haz, que con las alas alzadas cubría sus pavoncicos, con un mote que decía: "Cum pudore laeta foecunditas» (Junto al pudor la rica fecundidad), aludiendo a la naturaleza de aquella ave, que por eso la han consagrado a Juno, reina del cielo, según la opinión y vanidad de los gentiles» -p. 138- [fig. 13].

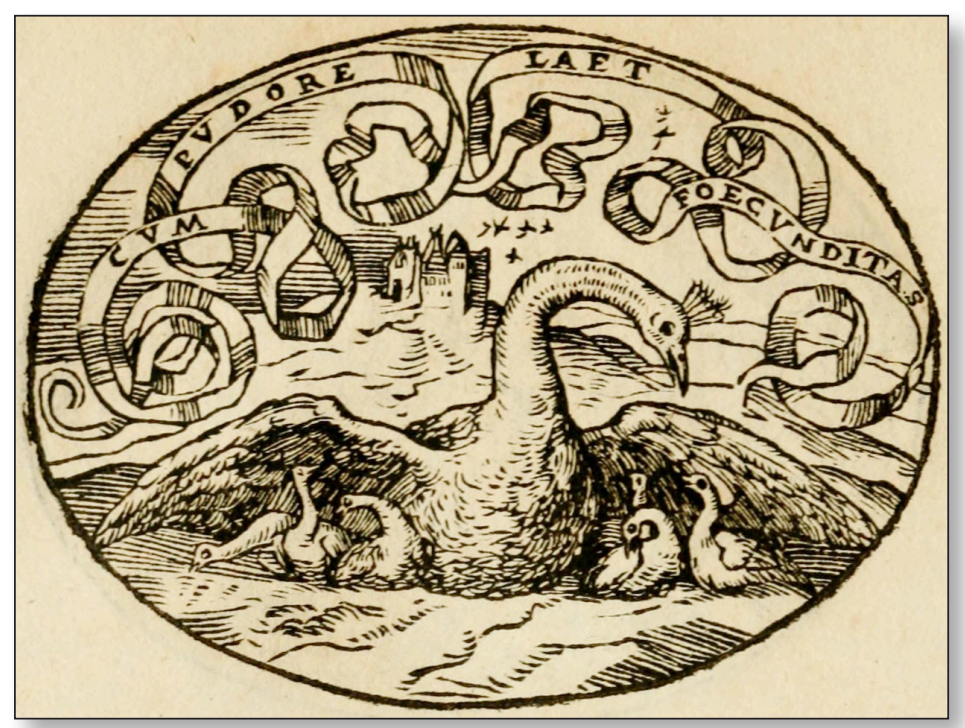

Fig. 13. Empresa de Leonor de Toledo. Paolo Giovio, Dialogo dell'imprese militare et amorose, Lyon, 1574. 150 
Un caso poco común es el que se da en la empresa de Marina de Aragón (ca.1484-1511), sobrina del rey Fernando el Católico, famosa por su hermosura, que sacó bordado en su atuendo de unas fiestas el mote: "Ninguno bien me parece / ni me merece». Ver para más detalle Maceiras (2017: reg. 399). Fernández de Oviedo, en sus Batallas y quincuagenas recoge la empresa de esta mujer porque establece diálogo con varias de un caballero (Alonso de Pimentel) que dedica a ella sus tres divisas ocasionales o invenciones. Lo que hoy nos pudiera parecer una descortesía de la dama, en la época era elogiado, siendo un desdén con agudeza lo único que podía esperar un caballero en público de una dama que se preciara de honesta.

\section{PROCEDIMIENTOS Y GUIÑOS AGUDOS}

Casos como el de Marina de Aragón, cuya invención establece diálogo con las divisas de un pretendiente, se dan también en una divisa de la que sería reina Juana (la Loca) como respuesta a una empresa de su esposo, el archiduque Felipe de Austria que se formulaba como pregunta: "Qui vouldra" (¿Quién querrá?), con que retaba a quien quisiera medirse con él en liza. Juana responde: "Ie le veus» (yo quiero). Las dos divisas-diálogo aparecen en el fol. 26r de The Hours of Joanna I of Castile, manuscrito conservado en The British Library, Londres. Add Ms. 18852. ${ }^{33}$

Muy impresionante es el uso combativo que dio a las divisas Ana Bolena mientras era amante del rey Enrique VIII, contra la reina Catalina de Aragón, cuando aún era su rival y esperaba suplantarla en el trono. Catalina usaba como divisa una empresa familiar de los Trastámara, una granada (López Poza, 2014: 88-93). La de Ana Bolena era el halcón blanco que procedía de la familia Butler. Ana bordó en seda su divisa [fig. 14] pero con el halcón comiéndose una apetitosa granada, con el

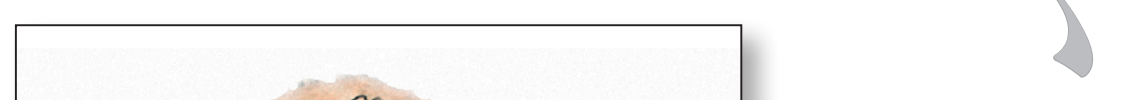
lema "Ainsi sera, groigne qui groigne" (así será, gruña quien gruña). El desafío fue mayúsculo, pues al acercarse la Navidad de 1530, mandó que sus criados llevaran como insignia en sus casacas esta divisa. Seguramente era

\footnotetext{
33. La divisa de Felipe tiene como mote a veces "Qui volet». La pictura mostraba a Felipe como caballero armado a caballo para un torneo, esperando en la tela de la liza a los combatientes que desearan medir con él sus fuerzas. Véase <https://www.bidiso.es/Symbola/divisa/162>
}

IMAGO, NÚM. 10, 2018, 75-97 
una respuesta a todos los que en la corte estaban de parte de la reina Catalina. Ana había pasado tiempo en la corte de Margarita de Austria, y allí seguramente vio un mote borgoñón que decía: «Groigne qui groigne et vive Bourgoigne» (Ives, 2004: 141).

Una práctica muy común en las divisas producidas en reinos españoles (y muy en especial en las ocasionales, en las invenciones para festejos) era el uso de juegos de agudeza verbal, como charadas, enigmas, adivinanzas, etc. Lo advirtió Gracián cuando exponía en su Agudeza y arte de ingenio:

Las propias de España son totalmente diversas déstas. Consiste su artificio no en la semejanza de la pintura con el intento que se pretende, sino en que el nombre de la cosa pintada, o solo o ayudado de otra palabra, exprima y diga lo que se pretende, de modo, que la pintura en éstos no representa tanto, cuanto sustituye por su voz y dicción. (Obras completas, ed. cit., 758).

Giovio censura estos usos, pues suelen salir «necias e imperfectas en cuanto a las condiciones [...] que les convienen», y lo mismo son criticadas por los teóricos porque solo podían ser entendidas por quienes usaran la misma lengua en que se hubieran compuesto; de lo contrario, perdían el sentido y serían empresas "sin alma». Sin embargo, fueron muy populares, y usadas fundamentalmente como divisas ocasionales, en fiestas con amplia participación popular.

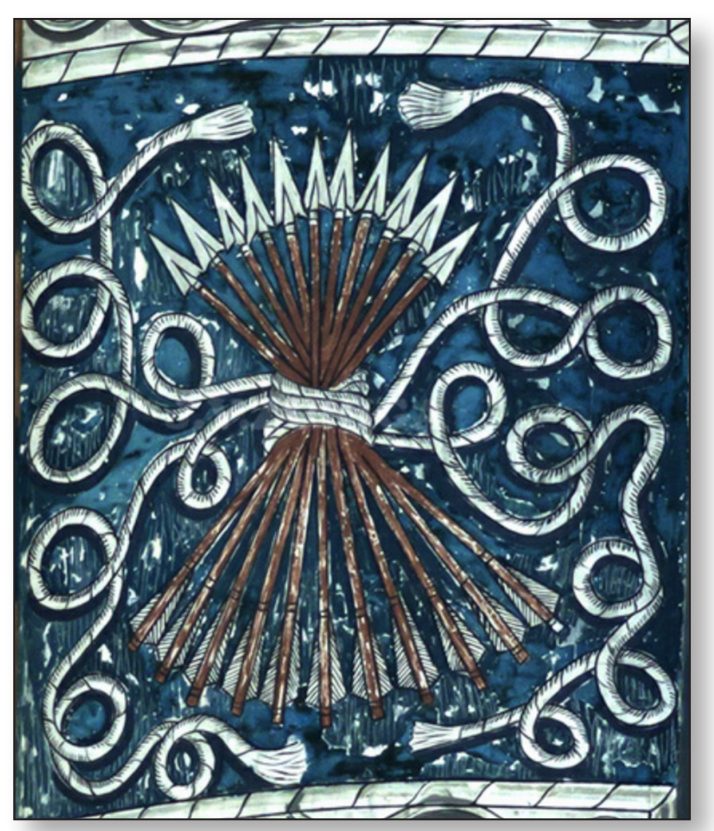

Fig. 15. Divisa de Isabel la Católica. Palacio de la Aljafería. Zaragoza

Una particularidad de divisas e invenciones españolas, como advierte Gonzalo Fernández de Oviedo y otros, es que, con frecuencia, el propietario de la divisa busca como motivo de la pictura uno cuyo nombre comience por la misma letra que el nombre de la amada o amado. Tenemos el caso en la divisa de la reina Isabel la Católica, cuya pictura eran unas flechas [fig. 15], porque su nombre comenzaba con la misma letra que el nombre de su esposo, 
Fernando, mientras que él tenía como motivo un yugo, nombre cuya inicial era la de Ysabel (tal como se escribía entonces). Las dos divisas comparten el mote "Tanto monta» y transmitía un mensaje a los súbditos rebeldes (recuérdese en qué circunstancias acceden al trono) de que o se sometían a la autoridad real (yugo) o se enfrentarían a las saetas, aludiendo a lo que Virgilio (Eneida VI, 851-853) sintetiza como forma de gobernar los pueblos con autoridad según el ideal imperial de Roma: perdonar a los vencidos y combatir a los soberbios. Amplios detalles sobre el sentido de la divisa de la reina Isabel en López Poza, 2012.34

De este tipo de empresas, principalmente de varones, hay muchos ejemplos entre las descritas por Fernández de Oviedo en Batallas y Quincuagenas, como una de Rodrigo de Ulloa, Señor de la Mota (c. 1415-1494), consejero de los Reyes Católicos, casado con Aldonza de Castilla. El motivo de su divisa era un armiño, cuyo nombre compartía inicial con el nombre de su esposa, y el mote (Él y vuestra condición / una misma cosa son) indicaba que en ella concurrían las virtudes que este animal simboliza: la pulcritud e inocencia (Maceiras, 2017, reg. 172).

Con cierta frecuencia, se advierten en retratos de damas anagramas usados como divisas. Isabella d'Este utilizó una divisa compuesta por una Y (inicial de su nombre) y dos letras griegas enlazadas, alfa y omega, (principio y fin). También la reina de Francia Catalina de Médici empleaba monogramas como forma de representación. La pintora italiana Sofonisba Anguisola (1535-1625), establecida en España, en la corte de Felipe II, empleó un complejo monograma en un autorretrato de hacia 1552 en miniatura conservado en el Museum of the Fine Arts, de Boston (Estados Unidos de América) ${ }^{35}$ : Sofonisba está representada de frente, sosteniendo un medallón muy grande a cuyo alrededor se distribuye un mensaje escrito en latín donde indica que hizo el autorretrato mirando en un espejo: «Sofonisba Anguissola vir[go] ipsius manu ex [s]peculo depictam Cremonae» y en el centro se ven varias letras enlazadas que se interpretan como una contracción del mote: "Anguis sola fecit victoriam» (Costa, 1999), en que se produce un juego entre su apellido y lo que significa en latín anguis (serpiente). Ese tipo de juegos, charadas, agudezas verbales con nombres o apellidos eran relativamente frecuentes.

\section{CONCLUSIÓN}

Dada la escasez de estudios dedicados a la modalidad genérica de la emblemática que conocemos como divisas o empresas históricas, no parece que se puedan aportar conclusiones prudentes, de momento, sobre el uso que de ella pudieron hacer las mujeres entre la segunda mitad del siglo XIV y finales del siglo XVII. Es muy reciente el enfoque interdisciplinar del estudio que permite una comprensión cabal del género, y hasta ahora no hemos dispuesto de un número suficiente de materiales para analizar.

En la pequeña porción de divisas de mujeres presentada (poco más de dos docenas) no parece que existieran diferencias notables entre divisas de mujeres y de hombres en lo relativo a estructura, implicación personal en el diseño, empleo de agudeza, etc., al menos en divisas personales de carácter heroico. En cuanto a las ocasionales o invenciones para ostentar en festejos públicos, el recato esperado de las mujeres en esos siglos las imponía res-

34. En la base de datos Symbola, <https://www.bidiso.es/Symbola/divisa/188>.

35. Puede verse en Internet: <https://Www.mfa.org/collections/object/self-portrait-33656>

IMAGO, NÚM. 10, 2018, 75-97 
tricciones y limitaciones para expresar con la misma libertad de los hombres mensajes que pudieran empañar su fama. Tal vez por ello Isabella d'Este empleara la agudeza extrema en ese tipo de divisas. Es posible que se usaran con más libertad en círculos restringidos y que no nos hayan quedado vestigios, o no los hayamos hallado aún. Por otra parte, la mujer era dedicataria de una gran cantidad de divisas empleadas por hombres en torneos y justas, y es preciso acometer un estudio sobre cómo eran representadas o aludidas las damas, qué mensajes se dan a ellas y sobre ellas, etc. Se abren amplias vías de trabajo en ese sentido, y la base de datos de acceso abierto Symbola se presenta como un instrumento de estudio que sin duda dará pronto resultados, al permitir recuperar información de manera más fácil que los catálogos impresos, cuya información la organizan de forma no homogénea (unos por propietario, otros por motivos representados, otros por motes), y muy pocos señalan divisas femeninas.

\section{BIBLIOGRAFÍA}

Bonoldi, L. [2015]. Isabella d'Este. A Renaissance Woman, translated by Clark Anthony Lawrence, Guaraldi - Engramma, Rimini.

Bregoli-Russo, M. [1990]. L'Impresa come ritratto del Rinascimento, Loffredo, Napoli.

Costa, P. [1999]. "Sofonisba Anguissola's Self-Portrait in the Boston Museum of Fine Arts", Arte Lombarda, 125 (1), 54-62.

Devise. Emblématique et héraldique à la fin du Moyen Age, base de datos, dirigida por Laurent Hablot, Centre d'Etudes Supérieures de Civilisation Médiévale, Université de Poitiers, [en línea] <http://base-devise.edel.univ-poitiers.fr /index.php>

Fernández de Córdova Miralles, A. [2016]. «El cordón y la piña. Signos emblemáticos y devociones religiosas de Enrique III y Catalina de Lancaster (1390-1418)", Archivo Español de Arte, LXXXIX, 354, abril-junio, 113-130.

Fernández de Oviedo, G. [1983-2002]. Batallas y quincuagenas; transcripción de José Amador de los Ríos y Padilla; prólogo y edición de J. Pérez de Tudela y Bueso, Madrid, Real Academia de la Historia, 1983-2002, $4 \mathrm{v}$.

Fernández de Oviedo, G. [1989]. Batallas y quinquagenas. Introducción de J. B. Avalle-Arce, Ediciones de la Diputación de Salamanca, Salamanca.

Ferro, G. [1623]. Teatro d'imprese, In Venetia, Apresso Giacomo Sarzina, 1623. Dos partes en un volumen, con paginación independiente.

Gerola, G. [1930]. "Un'impresa ed un motto di casa Gonzaga», Rivista d'arte, 12, 389-390.

Giovio, P. [1561]. Dialogo de las empresas militares, y amorosas..., Rovillé, Lyon.

Giovio, P. [1574]. Dialogo dell'imprese militare et amorose..., Rovillé, Lyon.

Gracián, B. [2001]. Baltasar Gracián, Agudeza y arte de ingenio, ed. L. Sánchez Laílla, Obras completas, Espasa Calpe, Madrid.

Graham, D. [2017]. "Preface, Prescription, and Principle: The Early Development of Vernacular Emblem Proto-theory in France», Janus, 6, 1-31.

Haвlot, L. [2008]. "La plante dans l'emblématique médiévale», en Actes des journées d'études La représentation des plantes dans le livre, dir. A.-S. Traineau-Durozoy, Poitiers, SCD, 8-12.

Навцот, L. [2009]: «Les princesses et la devise. L'utilisation politique de l'emblématique par les femmes de pouvoir à la fin du Moyen Age», en Femmes de pouvoir et pouvoirs de femmes dans l'Europe occidentale médiévale et moderne, PU de Valenciennes, Valenciennes, 163-183. 
Insignia ... IX. Insignia Veneta, Mantuana, Bononiensia, Anconitana, Urbinatia, Perugiensia - Manuscrito, Bayerische StaatsBibliothek, BSB Cod.icon. 274.

Ives, E. [2004]. The Life and Death of Anne Boleyn, Blackwell, Oxford.

Junio, A. [2013]. Emblemas, Estudio introductorio de B. Antón. Traducción, notas e índices de B. Antón y A. Espigares, Libros Pórtico, Zaragoza.

LóPez Poza, S., [2011]. "Nec spe nec metu y otras empresas o divisas de Felipe II», en R. ZAFra y J. Azanza (eds.), Emblemática Trascendente, Pamplona, Sociedad Española de EmblemáticaUniversidad de Navarra, 435-456. Accesible online: http://hdl.handle.net/2183/11765

López PozA, S., [2012]. «Empresas o divisas de Isabel de Castilla y Fernando de Aragón (los Reyes Católicos)», Janus. Estudios sobre el Siglo de Oro, 1, 1-38. <http://www.janusdigital. es/articulo.htm?id=5>.

López PozA, S., [2014]. "La divisa de las granadas del rey Enrique IV de Castilla y su estela posterior", Imago. Revista de Emblemática y Cultura Visual, 6, 81-95. <https://ojs.uv.es/index.php/IMAGO/article/view/4131>

López PozA, S., [2017]. "La base de datos Symbola de divisas o empresas históricas. Planteamiento y diseño conceptual», en Studia Aurea, 1 1, 93-109, número monográfico: Presente y futuro de la literatura áurea en las Humanidades Digitales, <http://studiaaurea.com/article/ view/v1 l-lopez>.

LuzIo, A. y RenIER, R. [1899]. Giornale storico della letteratura italiana, vol. XXXIII.

Maceiras Lafuente, A. [2017]. Empresas o divisas históricas: un catálogo basado en fuentes de 1511 a 1629, SIELAE \& Society for Emblem Studies, A Coruña.

MaffeI, S. [1999]. Paolo Givio. Scritti d'Arte. Lessico ed ecfrasi, Scuola Normale Superiore, Pisa.

Ménestrier, C. F. [1686]. La science et l'art des devises, Paris, Robert J. B. de La Caille). La edición incluye, con paginación independiente, un Discours ou il est traité de la nature des devises, et de leurs principales regles.

Narbona Cárceles, M. [2015-2015]. «El contenido devocional de las divisas: el azafrán y la olla ardiente de la reina de Aragón (1416-1458)», Emblemata, 20-21, 435-452.

Picinelli, P. [1687]. Mundus symbolicus, Hermanni Demen, Coloniae Agripinae.

Rasmussen, J. [1989]. Italian Majolica in the Robert Lehman Collection, The Metropolitan Museum fo Art, New York.

Rolet, A. [2007]. "Aux sources de l'emblème: blasons et devises», Littérature 145 (2007/1) 53-78. <https://www.cairn.info/resume.php?ID_ARTICLE=LITT_145_0053> [16/01/2017].

SHEPHARD, T. [2011]. "Constructing Isabella d'Este musical decorum in the visual sphere», Renaissance Studies, 25, 5, 684-706.

StRAdA, O. de, Symbola Romanorum imperatorum (imperii)... [BSB-Hss Cod.icon. 425].

Symbola: divisas o empresas históricas, base de datos de BIDISO (Biblioteca Digital Siglo de Oro), A Coruña (España), [en línea] https://www.bidiso.es/Symbola/

Typotius, J. [1601-1603]. Symbola Divina ef Humana Pontificum Imperatorum Regum I-III, Praga [s.n.]

Tyротіus, J. [1666]. Symbola Divina $\theta$ Humana Pontificum, Imperatorum, Regum. Accessit brevis $\theta$ facilis Isagoge, [s.n.] 
